\title{
What Does Good Language Learner (GLL) Say about Foreign Language Learning? A Story from an Indonesian Learner
}

\author{
Ribut Wahyudi \\ Faculty of Education, Victoria University of Wellington, New Zealand \\ Faculty of Humanities, Maulana Malik Ibrahim State Islamic University, Indonesia \\ E-mail: Ribut.Wahyudi@vuw.ac.nz \& r.wahyudi.vuw.nz@gmail.com
}

Doi:10.7575/aiac.alls.v.5n.1p.1

Received: 05/01/2014

URL: http://dx.doi.org/10.7575/aiac.alls.v.5n.1p.1

Accepted: 21/02/2014

\begin{abstract}
Learning a foreign language could either be problematic or simplistic. For those who have learnt a foreign language (e.g. English) for along period of time but no significant progress it might be discouraging. On the other hand, for the successful learner it might be just an "affordable price" to get through. This paper draws on a successful foreign language learning experience by an Indonesian learner of English. Having no English background, along with the learner's non-linear degree courses makes this success story unique. The data was taken through questionnaire sent through email and Facebook correspondence, in which the respondent answered the set of questions and the researcher clarified for further explanation if the answer was not clear enough. The result of the questionnaire seems to indicate that the respondent characterizes some characteristics of good language learners (Rubin, 1975). However, there are domains in which the respondent's personal narratives do differ with the characteristics of good language learners as has been described in the former studies.
\end{abstract}

Key words: good language learner, language learning strategy, and foreign language learning

\section{Introduction}

It is a common phenomenon that learning a second language may create problems for its learners. The problems vary from one learner to another. The ways how learners overcome the problems are thus very important to observe in second language learning. In my opinion, seeing the fact that Albard Khan (the Javanese learner in this case study) is not from an English Department background but proficient in English, might have employed good language learning strategies that direct him to the level of proficiency and that these strategies might be, to some extent, different from those investigated by many scholars. Furthermore, the strategies that he exercises might be "interesting combination". In this article, the informant's profile along with methodology is presented, followed by summary and discussion of research findings and conclusion. This paper merely focuses on how learning strategies, as one of the variables that determine the success of language learning, help language learners. Other variables such as motivation, personality and learning style of course also play a role in language learning.

\section{Informant's Profile}

The learner profiled in this paper is Albard Khan, 29 year old English teacher in Indonesia at the time this study was conducted (April 2009). He has a unique study background. He started studying at Islamic Elementary School, followed by Junior high school also at Islamic institution. He then went on studying at Vocational School in engineering and did a bachelor degree in Law in 1999. When he was doing his bachelor's degree, Albard Khan was the President of University Student English Forum (USEF) in 2001/2002 at the University of Jember, Jawa Timur, Indonesia. During this time running the organization, he had the chance to interact with a native speaker consultant, as well as made use the time to join both local and national English debate competitions. He was motivated to learn English because of a better career that he might get in real life (Instrumental motivation).

In late 2007 he joined ITP TOEFL Test administered by Gajah Mada University, Yogyakarta, Indonesia. In this test, he got 633 out of a possible 677. He was also joining 6 months English Intensive Teaching Training called English Language Training for Islamic Schools (ELTIS) at Indonesia-Australia Language Foundation (IALF) Bali 2008 for six months which was accredited by Cambridge University. Again in this case, he could learn English better from qualified native speaker instructor, multimedia resources, books, and others. Currently he is an English Master Trainer for Junior High School Teachers in East Java, Indonesia under AusAid Project. After, one year of joining the Master Trainer program, Albard was awarded Australian Development Scholarship (ADS). Recently he has completed master in Education from Flinders University, Australia.

In the process of ADS selection namely 9 January 2010 Albard got an excellent IELTS score. His overall band score is 7.5 out of 9 . His reading is 8.5 , speaking is 6.5 , listening is 7.5 and writing is 8 (Personal communication, 2012). 


\section{Methodology}

\subsection{Methods of Data Collection}

The data was taken through questionnaire done in one-month period 2009. Follow up question was made for unclear answers either from email and more his confirmation through in a later date Facebook, 2012. The questionnaire indicates that the study was conducted through cross sectional way. The author's direct contact with Albard while spending his undergraduate back in 2001-2003 in the same organization University Student English Forum (USEF), provides long term informal observation of informant's English progress. This makes the observation becomes more longitudinal (Dörnyei, 2007).

\subsection{Research Approach}

The approach of this study is narrative inquiry. This allows the informant to narrate 'a story or a collection of stories' which is paramount importance due to the 'variety of insights narrative' (Murray, 2009, p.47). Further it is explained that one of the areas in which narrative inquiry is used in applied linguistic research is in the area of learning strategies (Oxford \& Green, 1996).

\subsection{Research questions}

This research is intended to answer two research questions:

1. What types language learning strategies employed by the informant?

2. How the informant makes use of the strategies to develop his English competence?

\section{A Review of Literature on Good Language Learners and Learning Strategy}

The study on good language learner dates back to the work of Rubin (1975). In this work Rubin describes that good language learner is the one who: (1) is a willing and accurate guesser (2) has a strong drive to communicate and or to learn from communication, (3) are not inhibited (dare to make mistake), (4) is prepared to attend form (language patterns) (5) practices, (6) monitors his/her own and other's speech and (7) attends to meaning (p.45-47). Expanding the study, Griffiths (2008) edited a book on 'Lessons from Good Language Learners' both on leaner variable and learning variable. The learner variable discusses the characteristics of good language learners in relation to age, motivation, learning style, learning strategy, metacognition, beliefs, autonomy, gender, culture and aptitude. While the leaning variable explores the characteristics of good language learner in relation to four language skills (reading, listening, writing and speaking), vocabulary, grammar, functions, pronunciation, teaching/learning method, strategy instruction, error correction and task. Written by different scholars, this book is a complete reference for studies on good language learners (details, see Griffiths, 2008). Other related studies 'successful language learning in difficult situation' (Lamb, 2002), 'understanding good language learners from Vietnamese as a Foreign Language' (Ho, 2011).

Unlike the studies on good language learner, language learning strategy is explored later. In her seminal work, Oxford (1990, p.8) defines strategies as "specific actions taken by the learner to make easier, faster, more enjoyable, more selfdirected, more effective and more transferable to new situations" Another scholar (Chamot 1987 cited in Macaro 2001) explained it as techniques, approaches or deliberate actions that students take in order to facilitate the learning and recall of both linguistics and content area of information. The main idea that can be drawn from the above definitions is that strategy refers to a learner as an active agent, conscious actions, and goal. Furthermore Oxford (1990) divides learning strategies into memory strategies, cognitive strategies, compensation strategies, meta-cognitive strategies, affective strategies and social strategies (details, see Oxford, 1990).

The previous studies on good language learner and learning strategy in Indonesian setting are limited. Those are 'learner's motivation and learning strategies in English Foreign Language (EFI) in Indonesian context' (Mattarima \& Hamdan, 2011), 'language learning strategies of two Indonesian young learners' (Yusuf, 2012), language learning strategy and learning styles of beginning and intermediate learners (Djiwandono, 1998), beliefs about language learning (Erlenawati, 2002), how learners from different cultural background learn a foreign language (Lengkanawati, 2004), and three most important characteristics of good language learner (Yanto, 2011). It is obvious that a story on good language learners with the particular focus on the learner with non-English schooling background from Indonesian context is absent.

In this article, the combination of learner's strategies from good language learners' characteristics (GLL) by Griffiths (2008) and Learning Strategies (memory strategies, cognitive strategies, compensation strategies, meta-cognitive strategies, affective strategies and social strategies) by Oxford (1990) is employed.

\section{Discussion}

In this study, the strategies that Albard applies in his learning, to some extent, conform to higher level language learner characteristics that Griffiths (2008) outlined. The similar strategies are, expanding vocabulary, improving grammar, making the uses of multi-media resources, and having strategies to deal with reading, speaking and listening. While he does not plan what he learns in terms of setting the goals and objectives, identifying the purpose of language tasks, organizing, planning language tasks, finding about language learning as he learns English independently not from the classroom. This makes it slightly different with what have been summarized by Griffiths (2008) in that he managed his own learning in somewhat different ways, learning English from natural setting, whereas the good language learners described by Griffiths learn English from the classroom. 
It is also worth noting that in his story he said that while in undergraduate, he read lots of books regardless of the topics but finally became more selective after graduating from the university. Moreover, he also used to jot down the new vocabularies while reading and looked their meaning, but he abandoned the activity when reading at present and simply check the dictionary. These seem to indicate Takeuchi's (2003) notions that some strategies may relate to the certain stage of learning and the shift of learning strategies in accordance to one's learning stages.

The tolerance of ambiguity as one of the characteristics of successful language learners is also exercised by my respondent. He stated that he lets the vocabularies and expression pass if they appear less frequent and seriously look up to dictionary or asking to the more proficient learner for the high frequent ones. It is said that "learners who can tolerate moderate levels of ambiguity are more likely to persist in language learning"' Chapelle, 1983; Naiman, Frohlich, Stern, \& Tedesco, 1978, cited in Grace 1998, p.23) and 'to achieve more than those than those who cannot tolerate ambiguity" (Chapelle \& Roberts, 1986; Reiss, 1985; Ehrman, 1993, cited in Grace 1998, p.23). Furthermore, the tolerance of ambiguity has a positive correlation with reading comprehension (Kamran \& Maftoon, 2012).

His confessions on keeping on practicing when facing difficulties is one of characteristics of good language learners in Indonesian context (Erlenawati, 2002; Yanto, 2012). This also underlines good language learner as Rubin (1975) proposed, in which L2 learner engaged in active practice. Yanto (2011) noted that good or successful language learners make errors work for them meaning that they L2 learner's errors provide insightful learning explanation for them.

The other thing that might be in slightly different with GLL characteristics is the fact he admits to really need to improve writing skills as he hardly practices it as he does not have adequate channel to do it. To make clear insight on GLL, Griffiths (2008) summarized the activities chosen by higher level language learners as the following: 'the ability to manage their own learning (meta-cognitive), expand vocabulary, improve the grammar knowledge, use multimedia resources, have strategies involving the four language skills (reading, writing, listening, speaking)" (p.92). This might refer to the reality that Albard is not learning English in formal classroom, so that he is not required to have a lot of exercises for this. However, it is noticed that after six month ELTIS training at Indonesia-Australia Language Foundation (IALF), his IELTS overall band score is 7,5. His writing skills improved amazingly gaining 8 in the band score. This might be because he has recognized, mastered the genre of IELTS writing and able to present 'credible representation' of academic writing required in IELTS writing (Hyland, 2002; Matsuda \& Tardy, 2007 cited in DressenHammouda, 2008, p.239).

In undertaking his language learning, Albard Khan employs deductive reasoning (cognitive strategy), applying the general rules and applying them to English (Oxford, 1990). Deductive reasoning itself is " a kind of reasoning in which, roughly, the truth input of propositions (premises) logically guarantees the truth output of propositions provided that no mistake has been made in reason" (Schechetr, 2013). He answered that his first language (Javanese) does not have any relation with English so that he does not find that his Javanese facilitate his language learning experience. This might deal with the fact that that Javanese and English do not have similarities, like the case of English with Dutch or German (Mc Gregor, 2009), where English language learners of these backgrounds might learn English faster due the similarity of the languages.

This relates to what he usually does especially in guessing the meaning of words from the contexts (compensation strategies) and his background knowledge either in reading or listening. His level of proficiency might also be affected by his warm welcome to the idea of developing cultural understanding and becoming aware of other's thought and feeling so that he can interact with more and more friends (social strategy). This might help him improve his communicative competence. In this case, he is not trapped with language ego, the identity developed in reference to language he speaks (Brown, 2007). As it is said that language ego may inhibit a language learner in their learning process (Brown, 2007).

Albard is a kind of risk taker (Rubin, 1975) in that he experiments the new words by using them in real communications (social strategy) with his friends both when he was at USEF and ELTIS. This is a positive trait for a language learner in which he does not only receive the language but also produce it (see Griffiths, 2008). The change of his reading habit from unselective to selective readings (e.g. Law and English Teaching Methodology) might reflect that his interest has converged to these areas. This might mean that he wants to merely devote his time to his professional career. His language progress measurement through getting his ideas acrossed could be influenced by the fact that he focuses more on meaning and the use of language (meta-cognitive strategy). His belief that reviewing the material he learned would reinforce his knowledge denotes that he exercises meta-cognitive strategy (Oxford, 1990)

However, the fact that he reviews them occasionally might mean that he only prioritizes to review materials that help him more on his interest. His proficiency is also enhanced by his hobbies to watch American Movies (memory strategy), where he can spot the use of words in informal conversation besides he can learn how to pronounce words from the programs. According to him, this increases his vocabulary bank. This way might relate to the idea of controlling vocabulary learning in which learners need to know what "vocabulary to learn, how to go about learning it, and how to assess and monitor and monitor their progress" (Moir and Nation, 2008). This activity is usually done by higher level of learners (Griffiths, 2008).

Letting the infrequent words pass when he does not understand their meaning and looking up at dictionary as well as consulting to the expert when he finds frequent difficult appearing words in texts, is a helpful strategy. This is because he is not stuck in one word and only clarifies the important words that may be useful for him. Nation (2001) divided vocabulary into four categories: high frequency words, academic words, technical words, and low frequency words. The 
high frequency words involve content words such as: government, forest, production, adoption etc. Academic words are words appeared in academic texts such as policy, phase, adjusted, sustained etc. Technical words are "'the words that are closely related to the topic and subject area of text" (p.12) such as motivation, learning strategy, personality factors, aptitude are technical words in SLA, while low frequency words such as "zoned", "pioneering", "pastoral" counting merely over $5 \%$ in the academic text" (p.12).

Moreover, his confirmation that in solving the difficulties in speaking and writing he usually practices them indicates that he is highly motivated learner. Besides that he also may get better comprehension by doing these repetitions. This practice was also reflected in Erlenawati's research (2002) on Indonesian learner.

Albard seems also to exercise (affective strategy) well by saying that if he gets unexpected result of learning he will keep on studying and by abandoning dealing with English when he is tired. This is because he said this will create unpleasant perception, but his interest on the language grows stronger when he gets fresh. In this case he can manage the time when he can learn when not to learn. This is one of the characteristics of higher level learner (Griffiths, 2008). The fact that he exercises 6 strategies (from the most used to the least); guessing the meaning from the whole context, using dictionary, speculating with the language by using new vocabulary in communication anyway, extensive reading, skimming and scanning shows that as adult learner he has his own set patterns of learning (Harmer, 2001).

\section{Conclusion}

Learning strategy might be implemented in slightly different ways by good language learners. In this paper the learner does not seem to follow exactly the learning strategy proposed by scholars such as he did not plan his learning such as setting the goals and objectives, identifying purposes of language task etc. From the confession of the leaner in his narrative, reading diverse sources and watching American movies are facilitative in his learning process. He also believes that exercising new words in speaking is necessary. As the L2 learner coming from non-English department background, his emphasis of learning is on the meaning and use of English. As might other GLL learners do, he always uses the language in communication activities, experimenting and speculating the use of language. Another key aspect of his success in mastering English might be triggered by his instrumental motivation to have a better career for his future. This has been supported by the studies that motivation plays a significant role in the success of language learning (Dörnyei, 2008). This might also portray the fact 'specific motivational processes are related to the salience of the mastery and performance goals in actual classroom setting' (Ames \& Archer, 1988, p.260).

All the activities that Albard experienced in his learning seems to underline the five characteristics of language learners such as: "taking an active approach to the task of language learning, recognizing and exploiting the systematic nature of language, using the language they were learning for communication and interaction, managing their own affective difficulties with language learning, and monitoring their language learning performance" (Norton \& Toohey, 2001, p.309).

Albard's successful language learning experience is essential in that it depicts slightly different characteristics of L2 learner in employing his strategy in mastering English such as he never reviews the materials he has learnt. This might highlight one of the future research in learning strategy in which as Chamot (2005) stated that 'the study of language learning strategies will continue to develop as second language acquisition researchers seek to understand different learner characteristics and the complex cognitive, social, and affective processes involved in processing language input and using the language for a variety of purposes" (p.126).

Not exact match in the success story of language learning in relation to language learning strategy might encourage us to consider "what is normal activity and language learning strategy use" (Riding and Rayner 1998 cited in Dornyei 2005, p.165). They explained that strategic learning is "purposeful effort to select and then pursue learning procedures that they believe will increase individual learning effectiveness". It is further explained that an activity becomes strategic when it is appropriate for individual learner. Another worth noting notion is tactic, 'particular form of schemata', and strategic, 'a broader design or plan for approaching high level goal and it coordinates a set of tactics' (Winne, 2001, cited in Dornyei 2005, p.165). These leave us with more cautions for future research especially in generalizing or labeling language learning strategy studies.

The last, but not least, interesting ideas comes from Ehrman, Leaver and Oxford (2003 cited in Dörnyei, 2005, p.166). They stated that " a given learning strategy is neither good nor bad. It is essentially neutral until it is considered in context. A strategy is useful under the conditions: (a) the strategy relates well to the L2 task at hand, (b) the strategy fits the particular student's learning style preferences to one degree or another, and (c) the students employ the strategy effectively and link it with other relevant strategies". These points open more flexible space where L2 language learners could be successful in language learning through more a complex process in which learning strategy is merely one of the variables characterizing successful language learning by good language learner.

Acknowledgements: I would like to thank Dr Sara Cotterall on the earlier feedback of this article. This article is the development of one of her assignments in Principles of Language Learning and Teaching Course during my study in Graduate Certificate in TEFL at the Faculty of Education and Social Work, University of Sydney, Australia 2009. I would also thank my friend Albard Khan for sharing his foreign language learning history in this study. 


\section{References}

Ames, C \& Archer, J. 1988. Achievement goals in the classroom: Student's learning strategies and motivation process. Journal of Educational Psychology, 80, 3, 260-267. http://dx.doi.org/10.1037/0022-0663.80.3.260

Brown, H. D. 2007. Principles of language learning and teaching. New York: Pearson education

Chamot, A. U. 2005. Language learning strategy instruction: Current issues and research. Annual Review of Applied Linguistics. 25, 112-130. http://dx.doi.org/10.1017/S0267190505000061

Djiwandono, P. 1998. Language learning strategy and learning styles of beginning and intermediate learners. TEFLIN Journal, Volume IX, Number 1.

Dörnyei, Z. 2005. The psychology of the language learner: Individual differences in second language acquisition. London: Lawrence Erlbaum Associates.

Dörnyei, Z. 2007. Research methods in applied Linguistics. Oxford: Oxford University Press.

Dörnyei, Z. 2008. Motivation and good language learners. In Griffiths, C. (Ed).2008. Lessons from good language learners. Cambridge: Cambridge University Press

Dressen-Hammouda, D. 2008. From novice to disciplinary expert: Disciplinary identity and genre mastery, English for Specific Purposes, 27, 233-252. http://dx.doi.org/10.1016/j.esp.2007.07.006

Erlenawati. 2002. Beliefs about language learning: Indonesian learners' perspectives, and some Implications for classroom practices. Australian Journal of Education. 46 (3), $323 \mathrm{http}: / / \mathrm{dx}$. doi.org/10.1177/000494410204600306

Grace, C. 1998. Personality type, tolerance of ambiguity, and vocabulary retention in CALL. CALICO Journal, 15, 1945.

Griffiths, C. 2008. Learning strategies and good language learners. In Griffiths, C. (Ed) Lessons from good language learners. Cambridge: Cambridge University Press

Harmer, J. 2001. The practice of English language teaching. Essex: Longman

Ho, G. A. L. 2011. Understanding good language learners of Vietnamese as a foreign language. Electronic Journal of Foreign Language Teaching. 8, 2, 385-398.

Kamran, S.K. \& Maftoon, P. 2012. An analysis of the associations between ambiguity tolerance and EFL reading strategy awareness. English Language Teaching. 5, 3, 188-196.

Khan, A. (2009, April). Questioner on learning strategies. Email correspondence.

Khan, A. (2012, June). IELTS score. Facebook correspondence.

Lamb, M. 2002. Explaining successful language learning in difficult circumstances. Prospect, 17, 2, 35-52.

Lengkanawati, N.S. 2004. How learners from different cultural backgrounds learn a foreign language. Asian EFL Journal. 6 (1).

Macaro, E.2001. Learning strategies in foreign and second language classrooms. London: Continuum

Mattarima, K. \& Hamdan, A. R. 2011. Learner's motivation and learning strategies in English foreign language (EFI) in Indonesian context. Journal of Edupres. 1, 100-108.

Mc Gregor, W. 2009. An introduction to linguistics. London: Continuum.

Moir, J \& Nation, P. 2008. Vocabulary and good language learners. In Griffith (ed). Lessons from good language learners. Cambridge: Cambridge University Press.

Murray, G. 2009. Narrative inquiry. In J. Heigham \& R. A. Croker (eds). Qualitative research in Applied Linguistics: A practical introduction. New York: Palgrave Macmillan.

Nation, I.S.P. 2001. Learning vocabulary in another language. Cambridge: Cambridge University Press.

Noorton, B. \& Toohey, K. 2001. Changing perspectives on good language learners. TESOL Quarterly, 35, 2, 307-322. http://dx.doi.org/10.2307/3587650

Oxford, R, L. 1990. Language learning strategies: What every teacher should know. Boston: Heinle and Heinle Publishers

Oxford, R. \& Green, J. 1996. Language learning histories: Learners and teachers helping each other understand learning styles and strategies. TESOL Quarterly, 6(1), 20-23.

Rubin, J. 1975. What the "good language learner" can teach us? TESOL Quarterly. 9(1), 41-51. http://dx.doi.org/10.2307/3586011

Schechetr, J. 2013, Deductive reasoning. In H. Pashler (ed). The encyclopedia of the mind. San Diego: Sage Publication Inc.

Takeuchi, O. 2003. What can we learn from good language leaners? A qualitative study in Japanese foreign language context. System, 31, 385-392. http://dx.doi.org/10.1016/S0346-251X(03)00049-6

Yanto, T. 2011. The three important characteristics of good language learner. In http://bahasa.kompasiana.com/2011/07/15/the-three-most-important-characteristics-of-good-language-learners/

Accessed June 13, 2012.

Yusuf, S. 2012. Language learning strategies of two Indonesian young learners in the USA. International Journal of English Linguistics. 2, 4, 65-72. http://dx.doi.org/10.5539/ijel.v2n4p65. 